Article

\title{
Total Phenolic Content and Antioxidant Activity of Some Malvaceae Family Species
}

Adriana Maria Fernandes de Oliveira ${ }^{1}{ }_{*}$, Lilian Sousa Pinheiro ${ }^{2}$, Charlane Kelly Souto Pereira ${ }^{2}$, Wemerson Neves Matias ${ }^{2}$, Roosevelt Albuquerque Gomes ${ }^{2}$, Otemberg Souza Chaves ${ }^{2}$,

Maria de Fátima Vanderlei de Souza ${ }^{2}$, Reinaldo Nóbrega de Almeida ${ }^{2,3}$ and

Temilce Simões de Assis ${ }^{3}$

1 Universidade Federal de Campina Grande, Unidade Acadêmica de Ciências da Vida, CEP 58900-000, Cajazeiras, PB, Brazil

2 Programa de Pós-Graduação em Produtos Naturais e Sintéticos Bioativos, Centro de Ciências da Saúde, Universidade Federal da Paraíba, CEP 58051-970, João Pessoa-PB, Brazil; E-Mails: lilihaaa@hotmail.com (L.S.P.); charlane_kelly@ yahoo.com.br (C.K.S.P.); wnmathias21@yahoo.com.br (W.N.M.); roosevelt_ag@bol.com.br (R.A.G.); otemberg_sc@yahoo.com.br (O.S.C.); mfvanderlei@ltf.ufpb.br (M.F.V.S.); reinaldoan@uol.com.br (R.N.A.)

3 Departamento de Fisiologia e Patologia, Centro de Ciências da Saúde, Universidade Federal da Paraíba, CEP 58059-900, João Pessoa-PB, Brazil; E-Mail: temilce@yahoo.com.br

* Author to whom correspondence should be addressed; E-Mail: adrianamfoliveira@ gmail.com; Tel.: +83-3531-4300; Fax: +83-3531-3046.

Received: 16 August 2012; in revised form: 10 September 2012 / Accepted: 24 September 2012 / Published: 26 October 2012

Abstract: The antioxidant activity of four species of the Malvaceae family (Sidastrum micranthum (A. St.-Hil.) Fryxell, Wissadula periplocifolia (L.) C. Presl, Sida rhombifolia (L.) E. H. L and Herissantia crispa L. (Brizicky)) were studied using the total phenolic content, DPPH radical scavenging activity and Trolox equivalent antioxidant capacity (TEAC) assays. The antioxidant activity of the crude extract, phases and two isolated flavonoids, kaempferol 3,7-di-O- $\alpha$-L-rhamnopyranoside (lespedin) and kaempferol $3-O-\beta$-D-(6"-E-p-coumaroil) glucopyranoside (tiliroside) was determined. The results showed that there is a strong correlation between total polyphenol contents and antioxidant activity of the crude extract of Sidastrum micranthum and Wissadula periplocifolia; however, this was not observed between Sida rhombifolia and Herissantia crispa. 
The ethyl acetate $(\mathrm{EaF})$ phase showed the best antioxidant effect in the total phenolics, DPPH and TEAC assays, followed by the chloroform (CfF) phase, in most species tested. Lespedin, isolated from the EaF phase of $W$. periplocifolia and $H$. crispa may not be responsible for the antioxidant activity due to its low antioxidant activity (IC $\mathrm{I}_{50}$ : DPPH: 1,019.92 $\pm 68.99 \mathrm{mg} / \mathrm{mL}$; TEAC: $52.70 \pm 0.47 \mathrm{mg} / \mathrm{mL}$ ); whereas tiliroside, isolated from $W$. periplocifolia, $H$. crispa and $S$. micrantum presented a low $\mathrm{IC}_{50}$ value $(1.63 \pm 0.86 \mathrm{mg} / \mathrm{mL})$ compared to ascorbic acid in the TEAC assay.

Keywords: Malvaceae family; antioxidant activity; total phenolic content; DPPH assay; TEAC assay

\section{Introduction}

Reactive oxygen species (ROS), such as superoxide radicals, hydroxyl (OH) radicals and peroxyl radicals, are natural byproducts of the normal metabolism of oxygen in living organisms with important roles in cell signalling [1,2]. However, excessive amounts of ROS may be a primary cause of biomolecular oxidation and may result in significant damage to cell structure, contributing to various diseases, such as cancer, stroke, diabetes and degenerative processes associated with ageing [3,4]. Thus, antioxidants are important inhibitors of lipid peroxidation not only for food protection but also as a defense mechanism of living cells against oxidative damage [5]. Antioxidants have been shown to prevent the destruction of $\beta$-cells [6,7], and to prevent or inhibit oxidation processes in human body and food products [8].

Plant polyphenols with antioxidant capacity could scavenge reactive chemical species as well as minimise oxidative damage resulting from excessive light exposure. Some plant polyphenols are important components of both human and animal diets and they are safe to be consumed [9].

Food antioxidants such as $\alpha$-tocopherol, ascorbic acid, carotenoids, amino acids, peptides, proteins, flavonoids and other phenolic compounds might also play a significant role as physiological and dietary antioxidants [10]. Natural antioxidants are known to exhibit a wide range of biological effects including antibacterial, antiviral, antiinflammatory, antiallergic, antithrombotic and vasodilatory activities [11].

Antioxidant capacity is widely used as a parameter for medicinal bioactive components. Various methods are currently used to assess the antioxidant activity of plant phenolic compounds. ABTS $^{\bullet+}$ or $\mathrm{DPPH}^{\bullet}$ radical scavenging methods are common spectrophotometric procedures for determining the antioxidant capacities of components [12].

Assays based upon the use of $\mathrm{DPPH}^{\bullet}$ and $\mathrm{ABTS}^{\bullet+}$ radicals are among the most popular spectrophotometric methods for determination of the antioxidant capacity of food, beverages and vegetable extracts [13]. DPPH is a stable free radical that reacts with compounds that can donate a hydrogen atom. This method is based on the scavenging of DPPH through the addition of a radical species or an antioxidant that decolourizes the DPPH solution [14].

The Trolox equivalent antioxidant capacity assay (TEAC) is based on the ability of antioxidants to quench the long-lived ABTS radical cation, a blue/green chromophore with characteristic absorption at 
$734 \mathrm{~nm}$, in comparison to butylated hydroxyanisole (BHA), butylated hydroxytoluene (BHT), $\alpha$-tocopherol and Trolox, a water-soluble $\alpha$-tocopherol analogue [12].

The Malvaceae family consists of 243 genus and 4,225 species [15]. In Brazil, there are 35 genus and 400 species [16]. The species of this family are utilized in folk medicine as emollients, antipyretics, anti-inflammatory, diuretic, arthritis, gastrointestinal disorders [17,18], snake bites [19] and asthma [20].

Due to the ethnobotanical importance of the family and the absence of studies that prove their antioxidant activity, the aim of this study was to evaluate the antioxidant activity, using DPPH radical scavenging activity and Trolox equivalent antioxidant capacity, and the total phenolic content of the crude extract $(\mathrm{CE})$ and various phases depending on the species: ethyl acetate (EaF), aqueous (WtF), chloroform (CfF) hexane (HF), n-butanol (n-BF) or dichloromethane (DF) phases of plants of the Malvaceae family: Sidastrum micranthum, Wissadula periplocifolia, Sida rhombifolia and Herissantia crispa. The antioxidant activity of two flavonoids isolated from Wissadula periplocifolia and Herissantia crispa: kaempferol 3,7-di-O- $\alpha$-L-rhamnopyranoside (lespedin) and kaempferol 3-O- $\beta$-D-(6"-E-p-coumaroil) glucopyranoside (tiliroside) was also analyzed. Tiliroside was also isolated from Sidastrum micranthum.

\section{Experimental}

\subsection{General}

Ascorbic acid, 2,2'-azinobis-(3-ethylbenzothiazoline-6-sulphonic acid) (ABTS), 6-hydroxy-2,5,7,8tetramethylchromane-2-carboxylic acid (Trolox), potassium persulfate, Folin-Ciocalteau's reagent, 1,1-diphenyl-2-pycrylhydrazyl (DPPH) were purchased from Sigma Aldrich (St. Louis, MO, USA). Gallic acid and sodium carbonate were purchased from Fluka (Switzerland). All the chemicals were of analytical grade.

\subsection{Plant}

Leaves of the species under study where dried in an oven, at an average temperature of $40{ }^{\circ} \mathrm{C}$, for $96 \mathrm{~h}$. The dried leaves were macerated with ethanol (95\%), for $72 \mathrm{~h}$, at room temperature. The ethanol solution was concentrated under reduced pressure, at $50{ }^{\circ} \mathrm{C}$, affording the crude extract (CE). The CE was partitioned in ethanol- $\mathrm{H}_{2} \mathrm{O}$ (7:3), extracted with hexane, chloroform, ethyl acetate or $n$-butanol to give the corresponding phases with crescent polarities: hexane (HF), chloroform (CF), ethyl acetate (EaF), n-butanol (nBF), water (WtF) of the species Sidastrum micranthum (A. St.-Hill.) Fryxell, Wissadula periplocifolia (L.) C. Presl and Herissantia crispa L. (Brizicky), and hexane (HF), dichloromethane (DF), ethyl acetate (EaF), $n$-butanol (nBF) and water (WtF) for Sida rhombifolia.

Kaempferol 3-O- $\beta$-D-(6"-E- $p$-coumaroyl)-glucopyranoside (tiliroside-500 mg) was isolated from the EaF phase of W. periplocifolia (L.) C. Presl [21], S. micranthum (A. St.-Hil.) Fryxell and $H$. crispa L. (Brizicky) ethanolic crude extract. The kaempferol was purified by successive Sephadex LH-20 column chromatography eluted with methanol [21-23]. Kaempferol 3,7-di-O- $\alpha$-Lrhamnopyranoside (lespedin-200 mg) was isolated from the $n$-butanol phase (nBF) of the ethanolic crude extract of $W$. periplocifolia and H. crispa L. (Brizicky), using the same methodology [23]. 
Figure 1. Sidastrum micranthum (A. St.-Hil.) Fryxell.

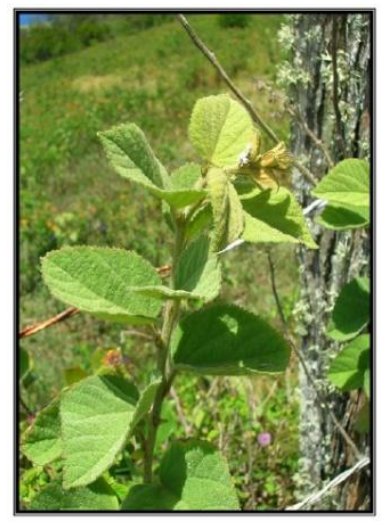

Figure 2. Wissadula periplocifolia (L.) C. Presl.

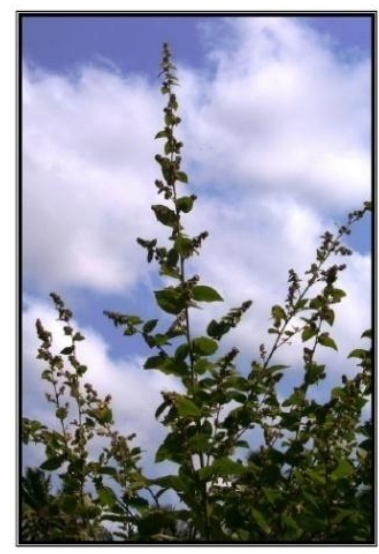

Figure 3. Herissantia crispa L. (Brizicky).

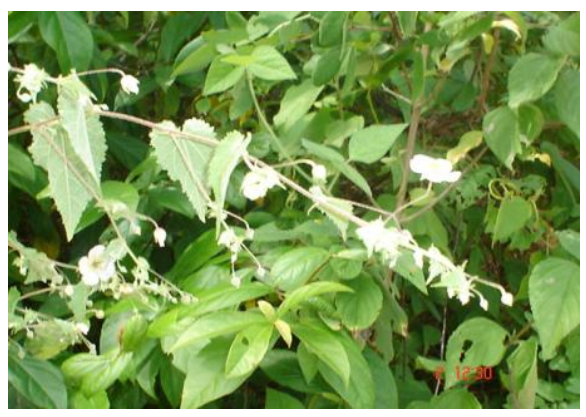

\subsection{Determination of Total Phenolic Contents}

The total phenolic content of the samples was determined using the Folin-Ciocalteau's reagent as described by Gulcin et al. [24]. An aliquot of the samples, dissolved in ethanol, was mixed with Folin-Ciocalteau's reagent $(100 \mu \mathrm{L})$ and distilled water $(3 \mathrm{~mL})$ and mixed for $1 \mathrm{~min}$. Sodium carbonate (300 $\mu \mathrm{L}, 15 \%$ ) was added to the mix. The solution had its volume adjusted to $5 \mathrm{~mL}$ with distilled water. After $2 \mathrm{~h}$, absorbance was measured at $760 \mathrm{~nm}$. A standard curve was prepared using gallic acid with a concentration range from 0.5 to $25 \mu \mathrm{g} / \mathrm{mL}$. Total phenolic content was expressed as $\mathrm{mg}$ gallic acid equivalents $(\mathrm{GAE}) / \mathrm{g}$ of samples. 


\subsection{DPPH Radical Scavenging Activity Assay}

The assay was performed according to Silva et al. [25]. An aliquot of the samples was mixed with DPPH solution ( $5 \mathrm{~mL}, 23.6 \mu \mathrm{g} / \mathrm{mL}$ in ethanol), followed by incubation of $30 \mathrm{~min}$. The absorbance of each sample was read at $517 \mathrm{~nm}$. Ascorbic acid $(0.9,1.9,3.9,4.9,6.9 \mu \mathrm{g} / \mathrm{mL})$ was used as positive reference. The percentage of scavenged DPPH was calculated using Equation (1):

DDPH scavenging activity $=100 \times\left(A_{\mathrm{c}}-A_{\mathrm{s}}\right) / A_{\mathrm{c}}$

where $A \mathrm{c}$ is the absorbance of the control and $A s$ is the absorbance of the sample. $\mathrm{IC}_{50}$ values calculated denote the concentration of the sample required to decrease the absorbance at $517 \mathrm{~nm}$ by $50 \%$.

\subsection{Trolox Equivalent Antioxidant Capacity Assay (TEAC)}

The ABTS free radical-scavenging activity of each sample was determined according to the method described by RE et al. [26]. The radical cation $\mathrm{ABTS}^{\bullet+}$ was generated by persulfate oxidation of ABTS. A mixture of ABTS $(7.0 \mathrm{mM})$ and potassium persulfate $(2.45 \mathrm{mM})$ was allowed to stand overnight at room temperature in the dark to form radical cation $\mathrm{ABTS}^{\bullet+}, 12-16 \mathrm{~h}$ prior to use. A solution was diluted with ethanol and absorbance measured, at $734 \mathrm{~nm}$. An aliquot of each sample was mixed with the solution of the radical cation $\operatorname{ABTS}^{\bullet+}(5 \mathrm{~mL})$, and the decrease of absorbance was measured at $734 \mathrm{~nm}$ after $10 \mathrm{~min}$. Trolox $(1.1,1.7,2.3,2.9,3.5 \mu \mathrm{g} / \mathrm{mL})$ was used as positive reference. $\mathrm{IC}_{50}$ values calculated denote the concentration of the sample required to decrease the absorbance at $517 \mathrm{~nm}$ by $50 \%$.

All experiments were performed in triplicate. The DPPH and TEAC data were expressed as $\mathrm{IC}_{50}(\mathrm{mg} / \mathrm{mL})$. Total phenolic content was expressed as $\mathrm{mg}$ gallic acid equivalents (GAE)/g. Linear regressions were performed to indicate the relationship between the total phenolic contents and data from the antioxidant assays.

\section{Results and Discussion}

The results of total phenolic contents and the antioxidant activity of the EEB and phases of Sidastrum micranthum are shown in Table 1. The ethyl acetate $(\mathrm{EaF})$ phase of this species, had the highest content of phenolic compounds (177.44 $\pm 16.21 \mathrm{mg} \cdot \mathrm{GAE} / \mathrm{g})$ and the highest TEAC $\left(\mathrm{IC}_{50}=2.267 \pm 0.377\right)$, showing a better result than the Trolox assay $\left(\mathrm{IC}_{50}=3.02 \pm 0.014\right)$. However, for the DPPH assay, the chloroform (CfF) phase showed better antioxidant activity $\left(\mathrm{IC}_{50}=24.7 \pm 0.306\right)$.

The results of the antioxidant assays of Wissadula periplocifolia are shown in Table 2. The EaF phase had the highest content of phenolic compounds (260.46 \pm 5.74$)$, as well as the best antioxidant activity in the DPPH assay $\left(\mathrm{IC}_{50}=20.52 \pm 0.16\right)$. The TEAC assay, the $\mathrm{CfF}$ phase showed better antioxidant activity $\left(\mathrm{IC}_{50}=23.98 \pm 0.03\right)$ compared to the other phases. This discrepancy in total antioxidant activity values depending on the method used indicates that both assays determine different aspects of the antioxidant capacity. Different radicals and mechanisms of reaction are occurring [27]. 
Table 1. Total polyphenol contents, DPPH radical scavenging activity and Trolox equivalent antioxidant capacity (TEAC) of Sidastrum micranthum.

\begin{tabular}{|c|c|c|c|}
\hline Sample Assay & $\begin{array}{c}\text { Total polyphenol contents } \\
(\mathrm{mg} \cdot \mathrm{GAE} / \mathrm{g})\end{array}$ & $\begin{array}{c}\mathrm{DPPH} \\
\left(\mathrm{IC}_{50}-\mathrm{mg} / \mathrm{mL}\right)\end{array}$ & $\begin{array}{c}\text { TEAC } \\
\left(\mathrm{IC}_{50}-\mathrm{mg} / \mathrm{mL}\right)\end{array}$ \\
\hline $\mathrm{CE}$ & $39.37 \pm 2.54$ & $125.733 \pm 0.291$ & $35.543 \pm 0.954$ \\
\hline $\mathrm{EaF}$ & $177.44 \pm 16.21$ & $147.533 \pm 2.786$ & $2.267 \pm 0.377$ \\
\hline $\mathrm{WtF}$ & $22.83 \pm 2.14$ & $111.123 \pm 0.963$ & $35.503 \pm 0.358$ \\
\hline $\mathrm{CfF}$ & $107.29 \pm 4.17$ & $24.7 \pm 0.306$ & $10.053 \pm 0.132$ \\
\hline $\mathrm{HF}$ & $17.59 \pm 1.74$ & $100.83 \pm 2.478$ & $34.447 \pm 0.468$ \\
\hline$n$-BF & $50.88 \pm 2.78$ & $159.267 \pm 6.02$ & $24.687 \pm 1.054$ \\
\hline Positive reference & - & $3.124 \pm 0.023$ & $3.02 \pm 0.014$ \\
\hline
\end{tabular}

Crude Extract (CE), ethyl acetate (EaF), aqueous (WtF), chloroform (CfF), hexane (HF), $n$-butanol ( $n$-BF), dichloromethane (DF). Positive reference DPPH: ascorbic acid. Positive reference TEAC: Trolox.

Table 2. Total polyphenol contents, DPPH radical scavenging activity and Trolox equivalent antioxidant capacity (TEAC) of Wissadula periplocifolia.

\begin{tabular}{|c|c|c|c|}
\hline Sample Assay & $\begin{array}{c}\text { Total polyphenol contents } \\
(\mathrm{mg} \cdot \mathrm{GAE} / \mathrm{g})\end{array}$ & $\begin{array}{c}\text { DPPH } \\
\left(\mathrm{IC}_{50}-\mathrm{mg} / \mathrm{mL}\right)\end{array}$ & $\begin{array}{c}\text { TEAC } \\
\left(\mathrm{IC}_{50}-\mathrm{mg} / \mathrm{mL}\right)\end{array}$ \\
\hline $\mathrm{CE}$ & $45.68 \pm 0.58$ & $114.28 \pm 0.60$ & $75.42 \pm 0.44$ \\
\hline $\mathrm{EaF}$ & $260.46 \pm 5.74$ & $20.52 \pm 0.16$ & $45.71 \pm 0.07$ \\
\hline $\mathrm{WtF}$ & $26.41 \pm 1.62$ & $129.11 \pm 0.64$ & $83.15 \pm 2.33$ \\
\hline $\mathrm{CfF}$ & $118.64 \pm 0.94$ & $54.92 \pm 0.52$ & $23.98 \pm 0.03$ \\
\hline $\mathrm{HF}$ & $23.89 \pm 0.89$ & $151.18 \pm 2.20$ & $92.78 \pm 0.52$ \\
\hline$n$-BF & $34.02 \pm 1.48$ & $91.28 \pm 0.43$ & $49.90 \pm 1.04$ \\
\hline Positive reference & - & $3.124 \pm 0.023$ & $3.02 \pm 0.014$ \\
\hline
\end{tabular}

Crude Extract (CE), ethyl acetate (EaF), aqueous (WtF), chloroform (CfF), hexane (HF), $n$-butanol ( $n$-BF), dichloromethane (DF). Positive reference DPPH: ascorbic acid. Positive reference TEAC: Trolox.

The EaF of the Sida rhombifolia had the highest content of phenolic compounds $(88.311 \pm 2.660 \mathrm{mg} \cdot \mathrm{GAE} / \mathrm{g})$ and the best antioxidant activity for the DPPH and TEAC assay $\left(\mathrm{IC}_{50}=70.503 \pm 1.629\right.$ and $20.580 \pm 0.271$, respectively), as shown in Table 3 .

Table 3. Total polyphenol contents, DPPH radical scavenging activity and Trolox equivalent antioxidant capacity (TEAC) of Sida rhombifolia.

\begin{tabular}{|c|c|c|c|}
\hline Sample Assay & $\begin{array}{c}\text { Total polyphenol contents } \\
(\mathrm{mg} \cdot \mathrm{GAE} / \mathrm{g})\end{array}$ & $\begin{array}{c}\text { DPPH } \\
\left(\mathrm{IC}_{50}-\mathrm{mg} / \mathrm{mL}\right)\end{array}$ & $\begin{array}{c}\text { TEAC } \\
\left(\mathrm{IC}_{50}-\mathrm{mg} / \mathrm{mL}\right)\end{array}$ \\
\hline $\mathrm{CE}$ & $38.22 \pm 0.43$ & $115.91 \pm 0.15$ & $75.70 \pm 1.45$ \\
\hline $\mathrm{EaF}$ & $88.31 \pm 2.66$ & $70.50 \pm 1.62$ & $20.58 \pm 0.27$ \\
\hline $\mathrm{WtF}$ & $3.01 \pm 0.32$ & $126.46 \pm 1.62$ & $67.67 \pm 0.38$ \\
\hline $\mathrm{DF}$ & $69.75 \pm 1.87$ & $87.99 \pm 0.26$ & $32.32 \pm 0.79$ \\
\hline $\mathrm{HF}$ & $16.50 \pm 0.19$ & $180.21 \pm 4.72$ & $112.02 \pm 0.29$ \\
\hline$n-\mathrm{BF}$ & $22.75 \pm 1.66$ & $111.88 \pm 1.50$ & $58.46 \pm 0.47$ \\
\hline Positive reference & - & $3.124 \pm 0.023$ & $3.02 \pm 0.014$ \\
\hline
\end{tabular}

Crude Extract (CE), ethyl acetate (EaF), aqueous (WtF), chloroform (CfF), hexane (HF), $n$-butanol (n-BF), dichloromethane (DF). Positive reference DPPH: ascorbic acid. Positive reference TEAC: Trolox. 
The CfF phase of Herissantia crispa, had the highest content of phenolic compounds $(142.397 \pm 0.555 \mathrm{mg} \cdot \mathrm{EAG} / \mathrm{g})$, and the best antioxidant activity for $\mathrm{DPPH}$ assay $\left(\mathrm{IC}_{50}=61.52 \pm 0.458\right)$ and TEAC assay $\left(\mathrm{IC}_{50}=27.127 \pm 0.567\right)$ (Table 4$)$.

Table 4. Total polyphenol contents, DPPH radical scavenging activity and Trolox equivalent antioxidant capacity (TEAC) of Herissantia crispa.

\begin{tabular}{|c|c|c|c|}
\hline Sample Assay & $\begin{array}{c}\text { Total polyphenol contents } \\
(\mathrm{mg} \cdot \mathrm{GAE} / \mathrm{g})\end{array}$ & $\begin{array}{c}\text { DPPH } \\
\left(\mathrm{IC}_{50}-\mathrm{mg} / \mathrm{mL}\right)\end{array}$ & $\begin{array}{c}\text { TEAC } \\
\left(\mathrm{IC}_{50}-\mathrm{mg} / \mathrm{mL}\right)\end{array}$ \\
\hline $\mathrm{CE}$ & $56.25 \pm 0.83$ & $120.06 \pm 3.10$ & $80.84 \pm 1.04$ \\
\hline $\mathrm{EaF}$ & $87.07 \pm 0.50$ & $107.09 \pm 2.22$ & $83.35 \pm 0.08$ \\
\hline $\mathrm{WtF}$ & $73.68 \pm 3.51$ & $173.23 \pm 0.93$ & $116.02 \pm 1.03$ \\
\hline $\mathrm{CfF}$ & $142.39 \pm 0.55$ & $61.52 \pm 0.45$ & $27.12 \pm 0.56$ \\
\hline $\mathrm{HF}$ & $45.76 \pm 2.39$ & $255.05 \pm 3.97$ & $150.20 \pm 3.30$ \\
\hline$n$-BF & $63.21 \pm 2.40$ & $97.93 \pm 0.68$ & $91.77 \pm 0.74$ \\
\hline Positive reference & - & $3.124 \pm 0.023$ & $3.02 \pm 0.014$ \\
\hline
\end{tabular}

Crude Extract (CE), ethyl acetate (EaF), aqueous (WtF), chloroform (CfF), hexane (HF), $n$-butanol ( $n$-BF), dichloromethane (DF). Positive reference DPPH: ascorbic acid. Positive reference TEAC: Trolox.

Only David et al. [28] have studied the methanolic extract of Herissantia crispa, reporting an $\mathrm{IC}_{50}$ value for the DPPH assay of $3.9 \mathrm{mg} / \mathrm{mL}$. However, other phases were not studied.

The Folin-Ciocalteu method, generally used to assay the total phenolic compound content also measures the total reducing capacity of a sample. Total phenolics generally correlate with redox and antioxidant capacities as measured by the TEAC or DPPH methods [29,30]. Many studies indicate a linear relationship between total phenolics and antioxidant activity [31-33]. A direct correlation between the three methods, in all species, was demonstrated by linear regression analysis. As shown in this study, there is a strong correlation between total polyphenol contents and the antioxidant activity $\left(r^{2}=0.929\right)$ of Sidastrum micranthum; as well as Wissadula periplocifolia $\left(\mathrm{r}^{2}=0.814\right)$ samples.

Liu et al. [34] showed that the correlations of total polyphenol content against the antioxidant activity based on the DPPH assay, TEAC assay, and FRAP (ferric ion reducing antioxidant power) assay of Ilex kudingcha were satisfactory ( $\mathrm{r}>0.812$ ). The results of that work indicated that polyphenols in kudingcha extracts are largely responsible for the antioxidant activities.

Phenolic compounds are ubiquitous bioactive compounds and a diverse group of secondary metabolites universally present in higher plants [35]. The Folin-Ciocalteu phenol reagent is used to obtain a crude estimate of the amount of phenolic compounds present in an extract. However, the assay has been shown nonspecific not only to polyphenols but to any other substance that could be oxidised by the Folin reagent as reported by various researchers, the poor specificity of the assay [36,37]. This statement may explain the low correlation between total polyphenol contents and the antioxidant activity of Sida rhombifolia and Herissantia crispa $\left(\mathrm{r}^{2}=0.618 ; \mathrm{r}^{2}=0.46\right.$, respectively). It is suggested, that non-phenolic substances are responsible for antioxidant activity in this species. This lack of relationship is in agreement with Anagnostopoulou et al. [38] who reported a $r^{2}$ value of 0.42 between TPC and DPPH for extract obtained from sweet orange peel.

Flavonoids are polyphenolic compounds with low molecular mass, found in leguminous, fruits, flowers, and leaves [39], having several biological activities, for example, anti-inflammatory [40,41] and antioxidant action [42]. Some flavonoids isolated from Malvaceae species [43,44], were: 
3,7,3',4'-tetrahydroxyflavone (quercetin); 5,7-dihydroxy-4'-methoxyflavone (acacetin); 7,4'-di-O-methylisoscutellarein; 5,8-dihydroxy-7,4'-dimethoxyflavone; 5,4'-dihydroxy-7-methoxyflavone (genkwanin) [22]; 5,4'-dihydroxy-3,7-3'-trimethoxyflavone (pachypodol); luteolin 7-O- $\beta$-D-glucopyranoside (cinaroside), $5,7,4^{\prime}$ trihydroxyflavone (apigenin); 5,7,3',4'-tetrahydroxyflavone (luteolin) [F]; kaempferol-3-O- $\beta$-D(6"-E-p-coumaroyl)glucopyranoside (tiliroside) [21-23,45-47] and kaempferol 3,7-di-O- $\alpha$-L-rhamnoside (lespedin).

Lespedin showed a high $\mathrm{IC}_{50}$ value for the $\mathrm{DPPH}\left(\mathrm{IC}_{50}=1,019.92 \pm 68.99\right)$ and TEAC assay $\left(\mathrm{IC}_{50}=52.70 \pm 0.47\right)$ (Table 5), which means that this flavonoid is not the main substance responsible for the antioxidant activity of the EaF phase of Wissadula periplocifolia. Tiliroside also showed a high $\mathrm{IC}_{50}$ value for the DPPH assay $\left(\mathrm{IC}_{50}=219.31 \pm 9.62\right)$, therefore, it cannot be responsible for the antioxidant activity of the $\mathrm{EaF}$ phase. However, for the TEAC assay, it exhibited a low $\mathrm{IC}_{50}$ value $\left(\mathrm{IC}_{50}=1.63 \pm 0.86\right)$, and may contribute to the antioxidant activity of the Eaf phase of Wissadula periplocifolia and Sidastrum micranthum.

Table 5. DPPH radical scavenging activity and Trolox equivalent antioxidant capacity (TEAC) of Tiliroside e Lespedin.

\begin{tabular}{|c|c|c|}
\hline Sample Assay & $\begin{array}{c}\text { DPPH } \\
\left(\mathrm{IC}_{50}-\mathrm{mg} / \mathrm{mL}\right)\end{array}$ & $\begin{array}{c}\text { TEAC } \\
\left(\mathrm{IC}_{50}-\mathrm{mg} / \mathrm{mL}\right)\end{array}$ \\
\hline Lespedin & $1,019.92 \pm 68.99$ & $52.70 \pm 0.47$ \\
\hline Tiliroside & $219.31 \pm 9.62$ & $1.63 \pm 0.86$ \\
\hline Positive reference & $3.124 \pm 0.023$ & $3.02 \pm 0.014$ \\
\hline
\end{tabular}

Positive reference DPPH: ascorbic acid. Positive reference TEAC: Trolox.

A study performed by Babbar et al. showed that phenolic compounds alone are not fully responsible for the antioxidant activity of plants. Other constituents such as ascorbates, reducing carbohydrates, tocopherols, carotenoids, terpenes, and pigments as well as the synergistic effect among them could possibly contribute to the total antioxidant activity [48].

\section{Conclusions}

In conclusion, species the Malvaceae family have a high content of phenolic compounds and a good antioxidant activity, therefore they can be used to treat several diseases in which there is an increase in free radical production. However, non-phenolic substances can be responsible for the antioxidant activity of Herissantia crispa. Therefore, further studies are needed to identify which phenolic compounds are responsible for the antioxidant activity of the species, and assess the way in which the phenolic substances contribute to this activity. Additional in vivo antioxidant assays are needed to confirm the potential use of these species in disease treatment.

\section{References}

1. Aruoma, O.I.; Cuppette, S.L. Antioxidant methodology; In In Vivo and in Vitro Concept; AOCS Press: Champaign, IL, USA, 1997; pp. 142-169. 
2. Cavas, L.; Yurdakoc, K. An investigation on the antioxidant status of the invasive alga Caulerpa racemosa var. cylindracea (Sonder) Verlaque; Huisman, et Boudoresque (Caulerpales, Chlorophyta). J. Exp. Mar. Biol. Ecol. 2005, 325, 189-200.

3. Ames, B.N. Dietary carcinogens and anticarcinogens: Oxygen radicals and degenerative diseases. Science 1983, 221, 1256-1264.

4. Wiseman, H.; Halliwell, B. Damage to DNA by reactive oxygen and nitrogen species: Role of inflammatory disease and progression to cancer. Biochem. J. 1996, 313, 17-29.

5. Halliwell, B. Reactive oxygen species in living systems: Source, biochemistry, and role in human disease. Am. J. Med. 1991, 91, 14-22.

6. Slonim, A.E.; Surber, M.L.; Page, D.L.; Sharp, R.A.; Burr, I.M. Modification of chemically induced diabetes in rats by vitamin E. Supplementation minimizes and depletion enhances development of diabetes. J. Clin. Invest. 1983, 71, 1282-1288.

7. Murthy, V.K.; Shipp, J.C.; Hanson, C.; Shipp, D.M. Delayed onset and decreased incidence of diabetes in BB rats fed free radical scavengers. Diabetes Res. Clin. Pr. 1992, 18, 11-16.

8. Diaz, M.N.; Frei, B.; Vita, J.E.; Keaney, J.F. Antioxidants and atherosclerotic heart disease. J. Med. Nutr. Eng. 1997, 337, 408-416.

9. Gulçin, I.; Berashvili, D.; Gepdiremen, A. Antiradical and antioxidant activity of total anthocyanins from Perilla pankinensis decne. J. Ethnopharmacol. 2005, 101, 287-293.

10. Shahidi, F. Antioxidants in food and food antioxidants. Nahrung 2000, 44, 158-163.

11. Cook, N.C.; Samman, S. Flavonoids: Chemistry, metabolism, cardioprotective effects and dietary sources. J. Nutr. Biochem. 1996, 7, 66-76.

12. Gulçin, I; Huyut, Z.; Elmastas, M.; Aboul-Enein, H.Y. Radical scavenging and antioxidant activity of tannic acid. Arab J. Chem. 2010, 3, 43-53.

13. Bendini, A.; Cerretani, L.; Pizzolante, L.; Toschi, T.G.; Guzzo, F.; Ceoldo, S.; Marconi, A.M.; Andreetta, F.; Levi, M. Phenol content related to antioxidant and antimicrobial activities of Passiflora spp. extracts. Eur. Food Res. Technol. 2006, 223, 102-109.

14. Krishnaiah, D.; Sarbatly, R.; Nithyanandam, R. A review of the antioxidant potential of medicinal plant species. Food Bioprod. Process 2011, 89, 217-233.

15. Stevens, P.F. Angiosperm phylogeny. Available online: http://www.mobot.org (accessed on 16 August 2012).

16. Barroso, G.M.; Peixoto, A.L.; Ichaso, C.L.F.; Costa, C.G.; Guimarães, E.F.; Lima, A.C. Sistemática de Angiospermas no Brasil 2; Imprensa Universitária: Viçosa, MG, Brazil, 1991.

17. Ahmed, Z.; Kazmi, S.N.H.; Malik, A. Phytochemical investigation of Abutilon pakistanicum. J. Nat. Prod. 1990, 53, 1342-1344.

18. Yesilada, E.; Gurbuz, I.A. Compilations of the studies on the anti-ulcerogenic effects of medicinal plants; In Recent Progress in Medicinal Plants; SCI Tech Publishing LLC: Houston, TX, USA, 2002.

19. Otero, R.; Núñez, V.; Barona, J.; Fonnegra, R.; Jiménez, S.L.; Osorio, R.G.; Saldarriaga, M.; Díaz, A. Snakebites and ethnobotany in the Colombia Part III: Neutralization of the haemorrhagic effect of Bothrops atrox venom. J. Ethnopharmacol. 2000, 73, 233-241.

20. Franzotti, E.M.; Santos, C.V.F.; Rodrigues, H.M.S.L.; Mourão, R.H.V.; Andrade, M.R.; Antoniolli, A.R. Anti-inflammatory, analgesic activity and acute toxicity of Sida cordifolia L. (Malva-branca). J. Ethnopharmacol. 2000, 72, 273-278. 
21. Gomes, R.A.; Nogueira, T.B.S.S.; Silva, D.A.; Agra, M.F.; Souza, M.F.V. Constituintes químicos de Wissadula periplocifolia (L.) C. Presl MALVACEAE. Available online: http://sec.sbq.org.br/ cdrom/34ra/resumos/T3865-1.pdf (accessed on 16 August 2012).

22. Gomes, R.A.; Ramirez, R.R.A.; Maciel, J.K.S.; Agra, M.F.; Souza, M.F.V.; Falcão-Silva, V.S.; Siqueira-Junior, J.P. Phenolic compounds from Sidastrum micranthum (A. St.-Hil.) fryxell and evaluation of acacetin and 7,4'-di-O-methylisoscutellarein as motulator of bacterial drug resistence. Quím. Nova. 2011, 34, 1385-1388.

23. Costa, D.A.; Matias, W.N.; Lima, I.O.; Xavier, A.L.; Costa, V.B.M.; Diniz, M.F.F.M.; Agra, M.F.; Batista, L.M.; Souza, M.F.V.; Silva, D.A. First secondary metabolites From Herissantia crispa (Brizicky) and the toxicity activity against Artemia salina leach. Quim. Nova. 2009, 32, 48-50.

24. Gulcin, I.; Sat, I.G.; Beydemir, S.; Elmastas, M.; Kufrevioglu, O.I. Comparison of antioxidant activity of clove (Eugenia caryophylata thunb) buds and lavender (Lavandula stoechas L.). Food Chem. 2004, 87, 393-400.

25. Silva, T.M.S.; Camara, C.A.; Lins, A.C.S.; Barbosa-Filho, J.M.; Silva, E.M.S.; Freitas, B.M.; Santos, F.A.R. Chemical composition and free radical scavenging activity of pollen loads from stingless bee Melipona subnitida Ducke. J. Food Compos. Analys. 2006, 19, 507-511.

26. Re, R.; Pellegrini, N.; Proteggente, A.; Pannala, A.; Yang, M.; Rice-Evans, C. Antioxidant activity applying an improved ABTS radical cation decolorization assay. Free Radical. Bio. Med. 1999, 26, 1231-1237.

27. Lizcano, L.J.; Bakkali, F.; Ruiz-Larrea, M.B.; Ruiz-Sanz, J.I. Antioxidant activity and polyphenol content of aqueous extracts from Colombian Amazonian plants with medicinal use. Food Chem. 2010, 119, 1566-1570.

28. David, J.P.; Meira, M.; David, J.M.; Brandão, H.N.; Branco, A.; Agra, M.F.; Barbosa, M.R.V.; Queiroz; L.P.; Giulietti, A.M. Radical scavenging, antioxidant and cytotoxic activity of Brazilian Caatinga plants. Fitoterapia 2007, 78, 215-218.

29. Tabart, J.; Kevers, C.; Pincemail, J.; Defraigne, J.O.; Dommes, J. Antioxidant capacity of black currant varies with organ, season, and cultivar. J. Agr. Food Chem. 2006, 54, 6271-6276.

30. Tabart, J.; Kevers, C.; Sipel, A.; Pincemail, J.; Defraigne, J.O.; Dommes, J. Optimisation of extraction of phenolics and antioxidants from black currant leaves and buds and of stability during storage. Food Chem. 2007, 105, 1268-1275.

31. Djeridane, A.; Yousfi, M.; Nadjemi, B.; Boutassouna, D.; Stocker, P.; Vidal, N. Antioxidant activity of some Algerian medicinal plants extracts containing phenolic compounds. Food Chem. 2006, 97, 654-660.

32. Kim, D.O.; Chun, O.K.; Kim, Y.J.; Moon, H.Y.; Lee, C.Y. Quantification of polyphenolics and their antioxidant capacity in fresh plums. J. Agr. Food. Chem. 2003, 51, 6509-6515.

33. Kim, D.O.; Jeong, S.W.; Lee, C.Y. Antioxidant capacity of phenolic phytochemicals from various cultivars of plums. Food Chem. 2003, 81, 321-326.

34. Liu, L.; Sun, Y.; Laura, T.; Liang, X.; Ye, H.; Zeng, X. Determination of polyphenolic content and antioxidant activity of kudingcha made from Ilex kudingcha C.J. Tseng. Food Chem. 2009, 112, 35-41.

35. Robards, K.; Prernzler, P.D.; Tucker, G.; Swatsitang, P.; Glover, W. Phenolic compounds and their role in oxidative processes in fruits. Food Chem. 1999, 66, 401-436. 
36. Escarpa, A.; Gonza'lez, M.C. Approach to the content of total extractable phenolic compounds from different food samples by comparison of chromatographic and spectrophotometric methods. Anal. Chim. Acta 2001, 427, 119-127.

37. Singleton, V.L.; Orthofer, R.; Lamuela-Raventos, R.M. Analysis of total phenols and other oxidation substrates and antioxidants by means of Folin-Ciocalteu reagent. Method Enzymol. 1999, 29, 152-178.

38. Anagnostopoulou, M.A.; Kefalas, P.; Papageorgiou, V.P.; Assimopoulou, A.N.; Boskou, D. Radical scavenging activity of various extracts and fractions of sweet orange peel (Citrus sinensis). Food Chem. 2006, 94, 19-25.

39. Harbone, J.B.; Williams, C.A. Advances in flavonoid research since 1992. Phytochemistry 2000, $55,481-504$.

40. Landolfi, R.; Mower, R.L.; Steiner, M. Modification of platelet function andarachidonic acid metabolism by bioflavonoids. Structure-activity relationships. Biochem. Pharmacol. 1984, 33, $1525-1530$.

41. Corrêa, M.F.P.; Melo, G.O.; Costa, S.S. Substâncias de origem vegetal potencialmente úteis na terapia da Asma. Rev. Bras. Farmacogn. 2008, 18, 785-797.

42. Trueba, G.P.; Sanchez, G.M. Los flavonóides como antioxidantes naturales. Acta Farm. Bonaerense. 2001, 20, 297-306.

43. Wollenweber, E.; Dörr, M. Exudate Flavonoids from aerial parts or Kitaibelia vitifolia (Malvaceae). Biochem. Systemat. Ecol. 1996, 24, 801.

44. Waage, S.K.; Hedin, P.A. Biologicaly-active flavonoids from Gossypium arboreum. Phytochemistry 1984, 23, 2509-2511.

45. Silva, D.A.; Silva, T.M.S.; Lins, A.C.S.; Costa, D.A.; Cavalcante, J.M.S.; Matias, W.N.; Souza, M.F.V.; Filho, R.B. Constituintes químicos e atividade antioxidante de Sida galheirensis ULBR. (malvaceae). Quim. Nova. 2006, 29, 1250-1254.

46. Cavalcante, J.M.S.; Nogueira, T.B.S.S.; Tomaz, A.C.A., Silva, D.A.; Agra, M.F.; Souza, M.F.V.; Carvalho, P.R.C.; Ramos, S.R.; Nascimento, S.C.; Gonçalves-Silva, T. Steroidal and phenolic compounds from Sidastrum paniculatum (L.) fryxell and evaluation of cytotoxic and anti-inflammatory activities. Quím. Nova. 2010, 33, 846-849.

47. Silva, D.A.; Costa, D.A.; Silva, D.F.; Souza, M.F.V.; Agra, M.F.; Medeiros, I.A.; Barbosa-Filho, J.M.; Braz-Filho, R. Flavonoides glicosilados de Herissantia tiubae (K. Schum) Brizicky (Malvaceae) e testes farmacológicos preliminares do canferol 3,7-di-O- $\alpha$-L-ramnopiranosídeo. Braz. J. Pharmacog. 2005, 15, 23-29.

48. Babbar, N.; Oberoi, H.S.; Uppal, D.S.; Patil, R.T. Total phenolic content and antioxidant capacity of extracts obtained from six important fruit residues. Food Res. Intern. 2011, 44, 391-396.

(C) 2012 by the authors; licensee MDPI, Basel, Switzerland. This article is an open access article distributed under the terms and conditions of the Creative Commons Attribution license (http://creativecommons.org/licenses/by/3.0/). 